\title{
Effects of Ramipril on the Hormone Concentrations in Serum of Hypertensive Patients
} \author{
Tuula I. Helenius ${ }^{3}$ and Jari J. Forsström ${ }^{4}$ \\ ${ }^{1}$ Central Laboratory, Turku University Central Hospital, Turku, Finland \\ 2 Department of Medicine, Turku University Central Hospital, Turku, Finland \\ ${ }^{3}$ Medix Clinical Laboratories, Espoo, Finland \\ ${ }^{4}$ Medical Informatics Research Centre in Turku (MIRCIT), Turku, Finland
}

Paula E. Grönroos ${ }^{1}$, Kerttu M. Irjala ${ }^{1}$, Risto K. Vesalainen ${ }^{2}$, Ilkka M. Kantola ${ }^{2}$, Veli-Matti T. Leinonen ${ }^{1}$,

Summary: The effects of the angiotensin-converting enzyme inhibitor ramipril on thirteen endocrinological tests were evaluated. These tests comprised serum follitropin, lutropin, prolactin, thyrotropin, free thyroxine, total thyroxine, free triiodothyronine, parathyrin, cortisol, testosterone, sex hormone binding globulin, androstenedione and dehydroepiandrosterone sulphate.

Eleven hypertensive outpatients, 9 men and 2 women, treated at the department of internal medicine in Turku University Central Hospital, received $5 \mathrm{mg}$ of ramipril once a day for the study period of four weeks. The above mentioned endocrinological tests were performed before and at the end of the ramipril treatment. Ramipril decreased the value of free thyroxine statistically significantly, $p=0.011$, from the mean value of $17.1 \mathrm{pmol} / 1$ to the mean value of $16.0 \mathrm{pmol} / 1$ when measured with Amerlex-MAB* free thyroxine kit. The mean within-subject difference was $-1.10 \mathrm{pmol} / 1$ with a $95 \%$ confidence interval of $-1.87--0.33 \mathrm{pmol} / 1$. With the AutoDELFIA ${ }^{\mathrm{TM}}$ free thyroxine kit and with the reference method dialysis+RIA no effect was detected. Other endocrinological tests examined were not affected by ramipril. Since the decreasing effect of ramipril on free thyroxine was detected only with Amerlex-MAB* but neither with AutoDELFIA ${ }^{\mathrm{TM}}$ nor with dialysis+RIA, the effect was concluded to be analytical. The underlying mechanism and the component ultimately interfering with the analysis is unknown.

\section{Introduction}

Drugs affect laboratory test results $(1,2)$. Drug effects on laboratory tests are either biological or analytical. For instance, amiodarone is known to increase the value of thyrotropin biologically (3-5) whereas several cephalosporines are known to interfere with current methods for measuring creatinine $(6,7)$.

The interfering drug effects should be known and they should also be recognized by clinicians in order to interpret laboratory test results correctly. Since new drugs and new laboratory methods are introduced frequently, laboratory staff should be alert and eager to actively search for drug effects on laboratory tests. For this purpose, it is not ethically suitable to treat healthy volunteers with drugs. However, related to other drug investigations, it is reasonable to also examine the unknown effects of investigational drugs on laboratory tests. This applies especially to endocrinological tests, which usually are not included in the safety tests of pharmaceutical industry but often, however, play an important role in clinical diagnostics.

Ramipril is a long-acting angiotensin-converting enzyme inhibitor, which is converted to its active metabolite, ramiprilat, in the liver (8). Even though ramipril was introduced into clinical use several years ago, little is known about its effects on endocrinological tests. Only the effects on the renin-angiotensin-aldosterone system $(9-11)$, cortisol, catecholamines, vasopressin (9) and insulin (12) have been studied. The present study was carried out to examine whether ramipril has other endocrinological effects.

\section{Materials and Methods}

Subjects

The study population consisted of 11 patients with essential hypertension, 9 men and 2 women, mean age 41.3 years (range 36-49 years). All subjects gave their informed consent to the study. One subject used low-dose budesonide and beclomethasone inhalations, others had no constant medication. All subjects had diastolic blood pressure between 95 and $110 \mathrm{~mm} \mathrm{Hg}$ repeatedly and the mean $24 \mathrm{~h}$-blood pressure in the ambulatory recording above $140 / 85 \mathrm{~mm}$ $\mathrm{Hg}$. The patients were examined by an internist to exclude secondary hypertension. Despite hypertension, the patients were healthy.

\section{Study protocol}

All subjects received the angiotensin-converting enzyme inhibitor ramipril $5 \mathrm{mg}$ (Ramace $5 \mathrm{mg}$ tabl, Suomen Astra Oy, Finland) once a day for the study period of four weeks. Subjects were tested for serum follitropin, lutropin, prolactin, thyrotropin, free thyrox- 
ine, total thyroxine, free triiodothyronine, parathyrin, cortisol, testosterone, sex hormone binding globulin, androstenedione and dehydroepiandrosterone sulphate before medication and at the end of the study period. Blood samples were taken between $7 \mathrm{a} . \mathrm{m}$. and $9 \mathrm{a} . \mathrm{m}$. after fasting from $10 \mathrm{p} . \mathrm{m}$. the previous evening. Methods, manufacturers and coefficients of inter-assay variation (CV\%) of the assays are displayed in table 1 . The study protocol was approved by the Ethics Committee of the Turku University Central Hospital and the study followed the recommendations for biomedical research involving human subjects according to the current version of the Declaration of Helsinki.

\section{Statistics}

The $95 \%$ confidence interval for the within-subject difference in a paired case was used as a measure of statistical significance. Student's t-test (paired, two-sided) was used to find out the exact pvalue (13).

\section{Results}

The effects of ramipril on the hormonal status of study patients are shown in table 2. Ramipril decreased the value of free thyroxine when measured with AmerlexMAB* (Amersham, UK): The mean value of free thyroxine before medication was $17.1 \mathrm{pmol} / 1$ and at the end of medication $16.0 \mathrm{pmol} / \mathrm{l}$. The mean within-subject difference was $-1.10 \mathrm{pmol} / 1$ with a $95 \%$ confidence interval of $-1.87 \mathrm{pmol} / 1--0.33 \mathrm{pmol} / 1$ and $\mathrm{p}=0.011$ (Student's t-test). When measured with AutoDELFIA ${ }^{\mathrm{TM}}$ (Wallac, Finland) the value of free thyroxine did not change statistically significantly, $p=0.268$. Neither did the value of free thyroxine change statistically signifi-

Tab. 1 Hormone assays: methods, manufacturers and coefficients of inter-assay variation (CV\%) at the given concentration.

\begin{tabular}{|c|c|c|c|c|}
\hline Assay & Method & Manufacturer & $\mathrm{CV} \%$ & at concentration \\
\hline Follitropin & DELFIA $^{\circledR}$ & Wallac & 3.3 & $0.8 \mathrm{U} / 1$ \\
\hline Lutropin & DELFIA $^{\circledR}$ & Wallac & 4.5 & $0.4 \mathrm{U} / 1$ \\
\hline Prolactin & AutoDELFIA ${ }^{\mathrm{TM}}$ & Wallac & 2.8 & $5.9 \mu \mathrm{g} / 1$ \\
\hline Thyrotropin & AutoDELFIA $^{\mathrm{TM}}$ & Wallac & 5.0 & $3.4 \mathrm{mU} / 1$ \\
\hline Free thyroxine & Amerlex-MAB* & Amersham & 5.4 & $18.7 \mathrm{pmol} / \mathrm{l}$ \\
\hline Free thyroxine & AutoDELFIA $^{\mathrm{TM}}$ & Wallac & 4.1 & $27.3 \mathrm{pmol} / 1$ \\
\hline Free thyroxine & Dialysis + RIA ${ }^{\mathrm{a}}$ & Medix Clinical Laboratories & 7.7 & $16 \mathrm{pmol} / \mathrm{h}$ \\
\hline Total thyroxine & DELFIA $^{\circledR}$ & Wallac & 3.6 & $92.2 \mathrm{pmol} / 1$ \\
\hline Free triiodothyronine & AutoDELFIA $^{\mathrm{TM}}$ & Wallac & 8.7 & $4.1 \mathrm{pmol} / 1$ \\
\hline Parathyrin & IRMA & Incstar & 13.1 & $45 \mathrm{ng} / 1$ \\
\hline Cortisol & Spectria RIA & Orion Diagnostica & 6.5 & $836 \mathrm{nmol} / 1$ \\
\hline Testosterone & Spectria RIA & Orion Diagnostica & 6.9 & $21.6 \mathrm{nmol} / 1$ \\
\hline Sex hormone binding globulin & Spectria IRMA & Orion Diagnostica & 7.0 & $10 \mathrm{nmol} / 1$ \\
\hline Androstenedione & Extraction + RIA & $\begin{array}{l}\text { Steranti Research (antiserum) } \\
\text { Amersham }\left(\left[{ }^{3} \mathrm{H}\right] \text { androstenedione) }\right.\end{array}$ & 11.0 & $3.8 \mathrm{nmol} / 1$ \\
\hline Dehydroepiandrosterone sulphate & RIA & Sorin Biomedica & 8.6 & $5.3 \mu \mathrm{mol} / 1$ \\
\hline
\end{tabular}

DELFIA: time-resolved fluoroimmunoassay;

IRMA: immunoradiometric assay.

RIA: radioimmunoassay;

${ }^{\text {a }}$ In-house method (see 1.c. (14)).

Tab. 2 Effects of ramipril on the serum hormonal status of study patients. In follitropin, lutropin, testosterone, sex hormone binding globulin, androstenedione and dehydroepiandrosterone sulphate values, only males are included.

\begin{tabular}{|c|c|c|c|c|c|c|}
\hline \multirow[t]{2}{*}{ Hormone } & & \multicolumn{2}{|c|}{$\begin{array}{l}\text { Before ramipril } \\
\text { treatment }\end{array}$} & \multicolumn{2}{|c|}{$\begin{array}{l}\text { After ramipril } \\
\text { treatment }\end{array}$} & \multirow{2}{*}{$\begin{array}{l}\Delta^{\mathrm{a}} \\
\text { Mean }\end{array}$} \\
\hline & & Mean & Range & Mean & Range & \\
\hline Follitropin & $\mathrm{U} / 1$ & 4.4 & $1.7-6.7$ & 4.4 & $2.2-6.4$ & -0.04 \\
\hline Lutropin & $\mathrm{U} / 1$ & 3.6 & $1.6-5.9$ & 3.0 & $2.2-4.2$ & -0.55 \\
\hline Prolactin & $\mu \mathrm{g} / 1$ & 7.1 & $4.0-11.0$ & 6.6 & $3.6-11.0$ & -0.45 \\
\hline Thyrotropin & $\mathrm{mU} / 1$ & 1.9 & $0.8-3.2$ & 1.6 & $1.1-2.4$ & -0.31 \\
\hline Free thyroxine $e^{b}$ & $\mathrm{pmol} / 1$ & 17.1 & $12.3-22.5$ & 16.0 & $13.5-21.9$ & $-1.10^{\mathrm{e}}$ \\
\hline Free thyroxine $e^{c}$ & $\mathrm{pmol} / \mathrm{l}$ & 12.2 & $9.4-14.6$ & 12.6 & $9.3-15.5$ & $0.35^{\mathrm{f}}$ \\
\hline Free thyroxine $e^{d}$ & $\mathrm{pmol} / 1$ & 13.5 & $10-17$ & 13.6 & $11-16$ & $0.10^{\mathrm{f}}$ \\
\hline Total thyroxine & $\mathrm{pmol} / 1$ & 113 & $74-150$ & 110 & $98-130$ & -3.0 \\
\hline Free triiodothyronine & $\mathrm{pmol} / 1$ & 5.9 & $4.9-7.7$ & 6.3 & $4.8-7.7$ & 0.38 \\
\hline Parathyrin & $\mathrm{ng} / 1$ & 36 & $17-57$ & 35 & $16-59$ & -0.5 \\
\hline Cortisol & $\mathrm{nmol} / \mathrm{l}$ & 465 & $232-635$ & 472 & $415-635$ & 6.9 \\
\hline Testosterone & $\mathrm{nmol} / 1$ & 18 & $9-28$ & 18 & $6-27$ & 0.3 \\
\hline Sex hormone binding globulin & $\mathrm{nmol} / \mathrm{l}$ & 36 & $14-56$ & 36 & $12-58$ & 0.1 \\
\hline Androstenedione & $\mathrm{nmol} / 1$ & 5.8 & $3.2-8.6$ & 5.6 & $4.1-9.3$ & -0.16 \\
\hline Dehydroepiandrosterone sulphate & $\mu \mathrm{mol} / 1$ & 6.8 & $2.8-11.1$ & 6.8 & $2.4-13.8$ & -0.09 \\
\hline
\end{tabular}




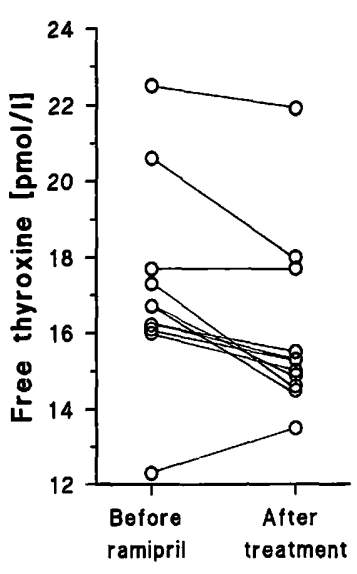

Fig. 1 Effects of ramipril on the free thyroxine values of individual patients measured with Amerlex-MAB*.

cantly, $\mathrm{p}=0.858$, when measured with the reference method dialysis + RIA (Medix Clinical Laboratories, Finland) (14). Ramipril did not affect other endocrinological tests. The effects of ramipril on free thyroxine of individual patients measured with Amerlex-MAB* are described in figure 1.

\section{Discussion and Conclusion}

The effects of angiotensin-converting enzyme inhibitors on endocrinological tests are not well known (2). Generally, angiotensin-converting enzyme inhibitors are shown to decrease serum aldosterone concentration and increase serum renin concentration (2), which also applies to ramipril $(9,11)$. Serum insulin has been found to decrease, increase or remain unaffected depending on the angiotensin-converting enzyme inhibitor (2). According to earlier studies, angiotensin-converting enzyme inhibitors do not affect the concentration of serum cortisol, catecholamines and antidiuretic hormone (2). Similarly, during ramipril treatment, the level of insulin secretion (12), cortisol, catecholamines and vasopressin (9) have been reported to remain unaffected.

In the present study, the effects of ramipril on 13 endocrinological tests were examined. No major endocrinological effects were found. Ramipril did not affect serum cortisol concentration, which is in line with the findings of Crozier and co-workers (9). Neither did ramipril have statistically significant effects on serum follitropin, lutropin, prolactin, thyrotropin, total thyroxine, free triiodothyronine, parathyrin, testosterone, sex hormone binding globulin, androstenedione or dehydroepiandrosterone sulphate concentrations.

However, serum free thyroxine decreased from the mean concentration of $17.1 \mathrm{pmol} / 1$ to the mean concentration of $16.0 \mathrm{pmol} / \mathrm{l}$ during ramipril treatment when measured with Amerlex-MAB*, which was the standard free thyroxine assay in our laboratory during the study. As the specimens were reanalyzed with the new AutoDELFIA $^{\mathrm{TM}}$ assay, no effect of ramipril was detected. Whenever an unexpected drug effect on a laboratory test is found, it is essential to assess the nature of the effect as analytical or biological. A biological effect causes a real increase or decrease of a biochemical component whereas an analytical effect is associated only with the method used in measuring. The minimal evidence needed for this classification requires at least two assays based on different methodological principles. To be certain about the nature of the effect, the specimens were reanalyzed using the reference method for free thyroxine, dialysis + RIA (14). The results of the dialysis+RIA were parallel with the AutoDELFIA ${ }^{\mathrm{TM}}$, i. e., no effect of ramipril on free thyroxine concentration was detected. Accordingly, the decreasing effect of ramipril on free thyroxine was associated with the Amerlex-MAB* but neither with the AutoDELFIA ${ }^{\mathrm{TM}}$ nor with dialysis + RIA. The decreasing effect of ramipril on free thyroxine was therefore concluded to be analytical.

Free thyroxine immunoassays have been strongly criticized because of the misleading diagnostic results they often yield due to abnormal serum concentrations of albumin or other proteins, antibodies or inhibitors of hormone binding $(15,16)$. Recently, Van Blerk and coworkers (17) compared four radioisotope immunoassays of free thyroxine and they evaluated the performance of Amerlex-MAB* free thyroxine as excellent. Endogenous albumin, however, was found to interfere with the method and have weak positive correlation with free thyroxine results. According to our measurements, ramipril did not affect the concentration of serum albumin (data not shown) and therefore albumin could not be the component interfering with the Amerlex-MAB* free thyroxine in this study. The mechanism of the effect is still unknown. All the same, the AutoDELFIA ${ }^{\mathrm{TM}}$ free thyroxine assay based on the back-titration principle was less sensitive to the interfering components in the specimens.

In Turku University Central Hospital we use a computerized system for managing patient medication data, laboratory data and drug-laboratory interference data $(18-20)$. Utilizing this system, we found that $20 \%$ of the patients tested for free thyroxine in our hospital were treated with an angiotensin-converting enzyme inhibitor. In the light of this finding and the fact that the Amerlex$\mathrm{MAB}^{*}$ assay is widely and commonly used, the effect of ramipril or possibly all angiotensin-converting enzyme inhibitors on free thyroxine is probably quite a common problem in laboratories. Even though the decrease in free thyroxine was slight and none of the patients in this study was misclassified as hypothyroid, attention should be paid to this problem, because misclassification of hyperthyroid patients as normal or normal patients as hypothyroid may occur in borderline cases. 


\section{References}

1. Salway JG. Drug-test interactions handbook. 1st ed. London: Chapman and Hall Medical, 1990.

2. Young DS. Effects of drugs on clinical laboratory tests. 4th ed. Washington: AACC Press, 1995.

3. Kennedy RL, Griffiths H, Gray TA. Amiodarone and the thyroid. Clin Chem 1989; 35:1882-7.

4. Davies PH, Franklyn JA. The effects of drugs on tests of thyroid function. Eur J Clin Pharmacol 1991; 40:439-51.

5. Surks MI, Sievert R. Drugs and thyroid function [review]. N Engl J Med 1995; 333:1688-94.

6. Nanji AA, Poon R, Hinberg I. Interference by cephalosporins with creatinine: measurement of creatinine by desk-top analyzers. Eur J Clin Pharmacol 1987; 33:427-9.

7. Green AJ, Halloran SP, Mould GP, Barbour HM, Pritchard JL, Hallworth MJ, et al. Interference by newer cephalosporins in current methods for measuring creatinine. Clin Chem 1990; 36:2139-40.

8. Bender N, Rangoonwala B, Rosenthal V, Vasmant D. Physicochemical and enzyme binding kinetic properties of a new angiotensin-converting enzyme inhibitor ramipril and their clinical implications. Clin Physiol Biochem 1990; 8 Suppl I:44-52.

9. Crozier IG, Ikram H, Nicholls MG, Jans S. Acute hemodynamic, hormonal and electrolyte effects of ramipril in severe congestive heart failure. Am J Cardiol 1987; 24:155D-63D.

10. Heintz B, Verho M, Brockmeier D, Kirsten R, Nelson K, Rangoonwala $\mathrm{B}$, et al. Influence of ramipril on plasma atrial natriuretic peptide, antidiuretic hormone, angiotensin II and aldosterone in patients with chronic congestive heart failure. Clin Physiol Biochem 1992; 9:113-8.

11. Sigurdsson A, Amtorp O, Gundersen T, Nilsson B, Remes J, Swedberg K. Neurohormonal activation in patients with mild or moderately severe congestive heart failure and effects of ramipril. The Ramipril Trial Study Group. Br Heart J 1994; 72:422-7.

12. Ludvik B, Kueenburg E, Brunnbauer M, Schernthaner G, Pager $R$. The effects of ramipril on glucose tolerance, insulin secretion, and insulin sensitivity in patients with hypertension. J Cardiovasc Pharmacol 1991; 18 Suppl 2:157-9.

13. Gardner MJ, Altman DG. Confidence intervals rather than $P$ values: estimation rather than hypothesis testing. $\mathrm{Br}$ Med $\mathrm{J}$ Clin Res Ed 1986; 292:746-50.

14. Helenius $T$, Liewendahl $K$. Improved dialysis method for free thyroxin in serum compared with five commercial radioimmunoassays in nonthyroidal illness and subjects with abnormal concentrations of thyroxin-binding globulin. Clin Chem $1983 ; 29: 816-22$.

15. Alexander NM. Free thyroxin in serum: labeled thyroxin-ana$\log$ methods fall short of their mark [editorial]. Clin Chem 1986; 32:417.

16. Ekins R. Validity of analog free thyroxin immunoassays. Clin Chem 1987; 33:2137-44.

17. Van Blerk M, Smitz J, Rozenski E, Mees M, Roelandt P, Laermans L, et al. Four radioisotopic immunoassays of free thyroxine compared. Ann Clin Biochem 1996; 33:335-43.

18. Grönroos P, Irjala K, Heiskanen J, Torniainen K, Forsström JJ. Using computerized individual medication data to detect drug effects on clinical laboratory tests. Scand J Clin Lab Invest 1995; 55 Suppl 222:31-6.

19. Grönroos P, Irjala K, Forsström JJ. Coding drug effects on laboratory tests for healthcare information systems. Proc Annu Symp Comput Appl Med Care 1995:449-53.

20. Grönroos P, Irjala K, Huupponen R, Scheinin H, Forsström J, Forsström JJ. A medication database - a tool for detecting and preventing drug interactions in hospital. Eur J Clin Pharmacol 1997. In press.

\section{Received November 25, 1996/March 13, 1997}

Corresponding author: Dr. Paula Grönroos, Central Laboratory, Turku University Central Hospital, Kiinamyllynkatu 4-8, FIN-20520 Turku, Finland 